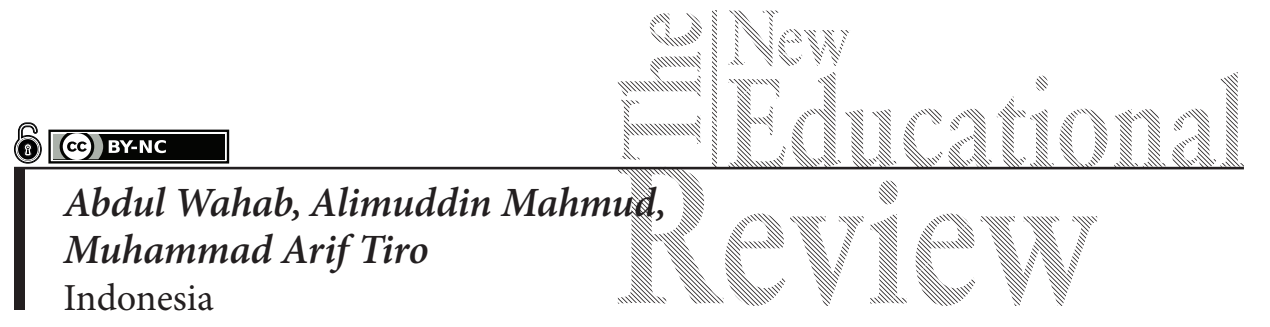

\title{
The Effectiveness of a Learning Module for Statistical Literacy
}

DOI: 10.15804/tner.2018.53.3.16

\begin{abstract}
Statistical literacy is the ability to master statistical concepts, applications, calculations and interpretations. This research is an experiment that aimed to investigate the effectiveness of a learning module for statistical literacy. The presented research focused on discussing and describing the effectiveness of a learning module for statistical literacy. The selected sample involved the public health students of STIKES BBM Majene; 20 students in class A as the sample for try-out I and 25 students in class B as the sample of try-out II by using One Group Pre-test and Post-test Design. The data was collected with the use of an achievement test of statistical literacy, and data was analyzed with the use of Descriptive Statistical Analysis, N-Gain Calculations, and Paired Sample t Test. Research results revealed that the average N-Gain in try-out I was 0.59 , and the average $\mathrm{N}$-Gain in try-out II was 0.61 , each of which was in the moderate category. Moreover, in try-out I, the mean score of the post-test was 22.15 , which was higher than and significantly different from the mean score of the pre-test, which was 10.66. Meanwhile, in try-out II, the mean score of the post-test was 22.68, which was higher than and significantly different from the mean score of the pre-test, which was 10.96 . Therefore, the learning module for statistical literacy was effective.
\end{abstract}

Keywords: statistical literacy, achievement, learning module. 


\section{Introduction}

Education is an important thing for everyone's life. Education is a conscious effort made by family, society and the government through teaching, research, service, guidance and practice activities taking place at universities. Learning is a process and is a fundamental element to every level of education. In the whole process of education, learning is the most basic and important activity.

Learning is a process or effort made by each individual to obtain a change in behavior in the form of knowledge, skills and positive attitudes and values as an experience to get some impression of the material that has been studied. A learning activity can be done on campus, at home, and in other places such as in a museum, in a laboratory, in a jungle and anywhere. Learning is complex action and behavior done by students. As an action, learning is only experienced by students themselves and will be a determinant of either the occurrence or non-occurrence of the learning process. Learning can occur without lecturers or without other formal teaching and learning activities.

Statistics is one of the sciences that underlie the development of educational technology, so students need to learn statistics in the form of subjects, namely Basic Statistics, Educational Statistics or Biostatistics. Statistics is a compulsory subject for students in every university, with the goal of equipping students with theoretical and practical knowledge.

Statistics can be viewed as a knowledge related to variability and becomes a means to explain the phenomenon of uncertainty that always happens in life, in the workplace, and in science itself (Moore, 1997). In particular, statistics is used to describe and predict phenomena that require the collection of measurement results. The question is what kind of essential basic capability provides students with direction, technology and information? Statistical Literacy is one of many basic skills. Gal (2002) states that Statistical Literacy includes the ability to master statistical concepts, the ability to use statistical applications, the ability to perform statistical calculations, and the ability to interpret statistical results.

Statistical literacy skill in the subject of statistics is considered not to show satisfactory results. Statistical learning activity in students' statistical literacy is still in the low category. Similarly, students are still less able to use statistical software with good statistical literacy.

The results of the observation revealed that the students of STIKES BBM had difficulty in understanding the teaching materials of the statistics subject as the language used seemed rigid so that the students could not learn much from the teaching materials. The students also used to understand the materials based on 
the explanation from their lecturer during the teaching and learning process. The lecturer-centered approach made the students' capabilities less explored and made the teaching and learning process last longer. This condition led to a less effective teaching and learning process.

The results of the observation of several lecturers of statistics showed that the lecturers required teaching materials that helped the students understand the materials, and that were interesting so as to improve the students' achievement. The lecturers required media in the form of teaching materials that were easy to use, easy to read and understand, adapted to the students' needs, and that could be used to study at home. The observation results revealed that the lecturers still had a high desire to use a learning module.

The advantages of using teaching materials made by the lecturer (module) include making them easier to learn by students, providing a lot of immediate feedback, promoting more complete mastery of materials, making students more motivated to complete the modules themselves according to their ability, and establishing cooperation between the lecturer and students. On the other hand, the advantages of using a learning module for lecturers include allowing the lecturer to perform an individualized approach to students without disrupting the environment around the students, increasing the professionalism of the lecturer as a learning module raises questions that encourage the lecturer to think and to behave more scientifically about their profession.

To cope with this problem, it is necessary to put forward a learning module that can improve students' learning achievement in statistics optimally so as to make learning more effective. This can be done by encouraging students to focus on the essential part of the statistics materials by providing review of that essential part. This review is done by packing the essential part in a learning module that must be studied and solved by students.

In an effort to improve students' learning achievement in statistics concerning either the process or the product, it is necessary to reform the learning approach and strategy. One strategy that can provide a solution to this problem is the more effective use of the learning module for statistical literacy.

\section{Research Problem}

Based on the above rationale, the research problem was formulated as: "What is the effectiveness of a learning module for statistical literacy in improving students' learning achievement in statistics? Then the objective of this research was to find out the effectiveness of a learning module for statistical literacy in improving students' learning achievement in statistics at STIKES BBM. 


\section{Research Methodology}

\section{Research General Background}

The presented research is an experimental study with one group pretest and posttest design with the sample size of 20 students of public health in class A for tryout I and 25 students of public health in class B for try-out II at STIKES BBM Majene.

The instrument used to determine the effectiveness of the statistical literacy learning was an achievement test of statistical literacy with simple linear regression as the learning material. This test consisted of 30 questions; 6 questions about basic knowledge, ten questions about the concept of simple linear regression, three questions about the application of simple linear regression, six questions about the calculation of simple linear regression, and five questions about the interpretation of simple linear regression.

Data was collected with the use of an achievement test of statistical literacy through pretest administration at the beginning of the meeting and post-test administration at the end of the meeting. The data was analyzed with the use of descriptive statistical analysis to find out students' statistical literacy achievement in the pre-test and post-test, by using N-Gain calculations to find out the improvement of the students' learning achievement in statistics, and by using paired sample t-test to find out if there was a significant difference between the students' statistical literacy learning achievement in the pre-test and post-test.

Normalized gain between pre-test and post-test scores is the calculation of the difference between pre-test and post-test scores and the difference between the ideal score and the pretest scores. The normalized gain was used to find out the improvement of the students' statistical literacy learning achievement after the teaching and learning process had been done. The formula of Normalized Gain according to Evelyn and Casey is the following:

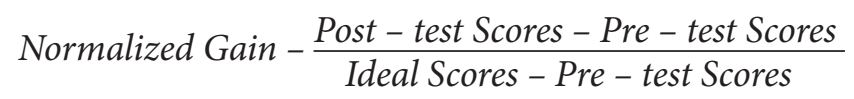

with the N-Gain criteria as in Table 1.

Table 1. Criteria of the $\mathrm{n}$-gain I

\begin{tabular}{cl}
\hline Mean & Criteria \\
\hline $\mathrm{g}>0.7$ & High \\
\hline $0.3 \leq \mathrm{g} \leq 0.7$ & Moderate \\
\hline $0 \leq \mathrm{g}<0.3$ & Low \\
\hline $\mathrm{g} \leq 0$ & Failed \\
\hline
\end{tabular}


Normality was tested using the Kolmogorov-Smirnov test. In this case, if the probability value was less than the significance level of 0.05 , then the distribution was not normal, and, on the other hand, if the probability value was greater than the level of significance of 0.05 , then the distribution was normal.

The homogeneity was tested using Levene's test. In this case, if the probability value was less than the significance level of 0.05 , then the distribution of variances was not homogeneous, and, on the other hand, if the probability value was greater than the level of significance of 0.05 , then the distribution of variances was homogeneous.

The test of significance was performed on two samples, namely the pre-test and post-test. This test was performed to find out the effectiveness of the learning module for statistical literacy. In this case, if the probability value was less than the level of significance of 0.05 , then $\mathrm{H} 0$ was rejected or there was a significant difference, and, on the other hand, if the probability value was greater than the level of significance of 0.05 , then $\mathrm{H} 0$ was accepted or there was no significant difference in the students' statistical literacy learning achievement between the pretest and posttest.

\section{Research Results}

\section{Statistical literacy learning achievement in the pre-test and post-test in try-out I}

Ideally, a correct answer was given a score of 1 and a wrong answer is given a score of 0 , then converted to a 1-100 score scale. The result of the analysis of the pretest revealed that the lowest and the highest scores were 26.67 and 46.67, respectively, the mean score was 35.5 with a standard deviation of 6.05 . On the other hand, the result of the analysis of the posttest showed that the lowest and the highest scores were 60 and 86.67, respectively; the mean score was 73.83 with a standard deviation of 8.33 . The frequency distribution of each category is presented in Table 2.

Based on the frequency distribution in Table 2, it can be seen that among 20 respondents who were pre-tested there were 10 respondents $(50 \%)$ whose learning achievement was in the low category, and 10 respondents (50\%) whose learning achievement was categorized as very low. On the other hand, in the posttest, there was 1 respondent (5\%) whose learning achievement was in the very high category, 15 respondents (75\%) whose learning achievement was categorized 
Table 2. The frequency distribution of the achievement test of statistical literacy of the pre-test and post-test in try-out I

\begin{tabular}{lcccrcc}
\hline \multirow{2}{*}{ Category } & \multirow{2}{*}{$\begin{array}{c}\text { Interval } \\
\text { Score }\end{array}$} & \multicolumn{2}{c}{ Frequency } & \multicolumn{2}{c}{ Percentage } \\
\cline { 3 - 7 } & Pre-test & Post-test & Pre-test & Post-test \\
\hline Very High & $85-100$ & 0 & 1 & 0.0 & 5.0 \\
\hline High & $65-84$ & 0 & 15 & 0.0 & 75.0 \\
\hline Fair & $55-64$ & 0 & 4 & 0.0 & 20.0 \\
\hline Low & $35-54$ & 10 & 0 & 50.0 & 0 \\
\hline Very Low & $0-34$ & 10 & 0 & 50.0 & 0 \\
\hline Total & & & 20 & & & 100 \\
\hline
\end{tabular}

as high, and 4 respondents (20\%) had their learning achievement in the very high category.

The description of statistical literacy learning achievement in the pre-test and post-test in try-out I is shown in Figure 1.

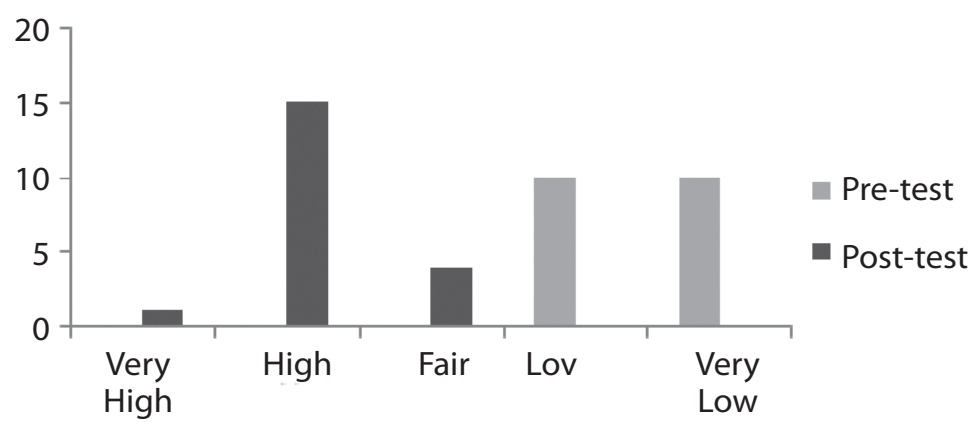

Figure 1. Statistical literacy learning achievement in the pre-test and posttest in try-out I

\section{$\mathrm{N}$-Gain calculation of statistical literacy learning achievement in the pre-test and post-test in try-out I}

$\mathrm{N}$-Gain analysis of the statistical literacy learning achievement in the pre-test and post-test is presented in Table 3 . 
Table 3. N-Gain analysis of the statistical literacy learning achievement in the pre-test and post-test in try-out I

\begin{tabular}{|c|c|c|c|c|c|}
\hline No & Pre-test & Post-test & Difference & N-Gain & Improvement \\
\hline 1 & 10 & 20 & 10 & 0.50 & Moderate \\
\hline 2 & 8 & 20 & 12 & 0.55 & Moderate \\
\hline 3 & 12 & 25 & 13 & 0.72 & High \\
\hline 4 & 9 & 23 & 14 & 0.67 & Moderate \\
\hline 5 & 14 & 22 & 8 & 0.50 & Moderate \\
\hline 6 & 11 & 22 & 11 & 0.58 & Moderate \\
\hline 7 & 9 & 22 & 13 & 0.62 & Moderate \\
\hline 8 & 12 & 25 & 13 & 0.72 & High \\
\hline 9 & 10 & 19 & 9 & 0.45 & Moderate \\
\hline 10 & 13 & 25 & 12 & 0.71 & High \\
\hline 11 & 9 & 24 & 15 & 0.71 & High \\
\hline 12 & 11 & 26 & 15 & 0.79 & High \\
\hline 13 & 10 & 24 & 14 & 0.70 & High \\
\hline 14 & 9 & 22 & 13 & 0.62 & High \\
\hline 15 & 13 & 18 & 5 & 0.29 & Low \\
\hline 16 & 8 & 22 & 14 & 0.64 & Moderate \\
\hline 17 & 12 & 25 & 13 & 0.72 & High \\
\hline 18 & 11 & 22 & 11 & 0.58 & Moderate \\
\hline 19 & 9 & 19 & 10 & 0.48 & Moderate \\
\hline 20 & 13 & 18 & 5 & 0.29 & Low \\
\hline Mean & 10.65 & 22.15 & 11.50 & 0.59 & Moderate \\
\hline
\end{tabular}

Table 3 reveals that 7 or $35 \%$ of the students improved their statistical literacy learning achievement in the high category, 11 or $55 \%$ of the students improved their achievement in the moderate category, and 2 or $10 \%$ of the students were in the low category. The mean score of the $\mathrm{N}-$ Gain was 0.59 , i.e., the improvement of the students' learning achievement was in the moderate category.

\section{Normality Test}

The result of the Kolmogorov-Smirnov test revealed that the probability value of the pre-test was 0.139 , which was greater than the level of significance of 0.05 , then the distribution was normal. Meanwhile, the probability value of the post-test was 0.105 , which was greater than the level of significance of 0.05 , then the distribution 
was also normal. It means that in the level of significance of $5 \%, \mathrm{~N}-\mathrm{Gains}$ of the pre-test and post-test scores of the statistical literacy learning achievement came from normally distributed population.

\section{Homogeneity Test}

The result of the homogeneity test with the use of Levene's test showed that the probability value was 0.264 , which was greater than the level of significance of 0.05 , then the distribution of variances of the pre-test and post-test was homogeneous. It means that at the level of significance of 5\%, N-Gains of the pre-test and post-test scores of the statistical literacy learning achievement came from homogeneous population.

\section{Test of significance of the learning achievement test}

The result of the test of significance through $t$ test revealed that the probability value was 0.00 , smaller than the level of significance of 0.05 , then $\mathrm{H} 0$ was rejected. It means that at the level of significance of $5 \%, \mathrm{~N}$-Gains of the pre-test and post-test scores of the statistical literacy learning achievement were significantly different.

\section{Statistical literacy learning achievement in the pre-test and post-test in try-out II}

Based on the result of the analysis, in the pre-test, the lowest and the highest scores were 26.67 and 46.67, respectively, the mean score was 36.53 with a standard deviation of 5.48. Meanwhile, in the post-test, the lowest and the highest scores were 56.67 and 86.67 , respectively, the mean score was 75.60 with a standard deviation of 7.92. The frequency distribution of each category is presented in Table 4.

Table 4. The frequency distribution of the achievement test of statistical literacy of the pre-test and post-test in try-out II

\begin{tabular}{lccccc}
\hline \multirow{2}{*}{ Category } & \multirow{2}{*}{ Interval Score } & \multicolumn{2}{c}{ Frequency } & \multicolumn{2}{c}{ Percentage } \\
\cline { 2 - 6 } & & Pre-test & Post-test & Pre-test & Post-test \\
\hline Very High & $85-100$ & 0 & 2 & 0.0 & 8.0 \\
\hline High & $65-84$ & 0 & 20 & 0.0 & 80.0 \\
\hline Fair & $55-64$ & 0 & 3 & 0.0 & 12.0 \\
\hline Low & $35-54$ & 14 & 0 & 56.0 & 0 \\
\hline Very Low & $0-34$ & 11 & 0 & 44.0 & 0 \\
\hline Total & & & 25 & & \\
\hline
\end{tabular}


The frequency distribution in Table 4 revealed that among 25 respondents who received the pre-test there were 14 respondents (56\%) whose learning achievement was categorized as low, and 11 respondents (44\%) fell into the very low learning achievement category, whereas in the post-test, 2 respondents $(8 \%)$ had their learning achievement categorized as very high, 20 respondents (80\%) fell into the high learning achievement categoty, and 3 respondents (12\%) had learning achievement that was categorized as very high.

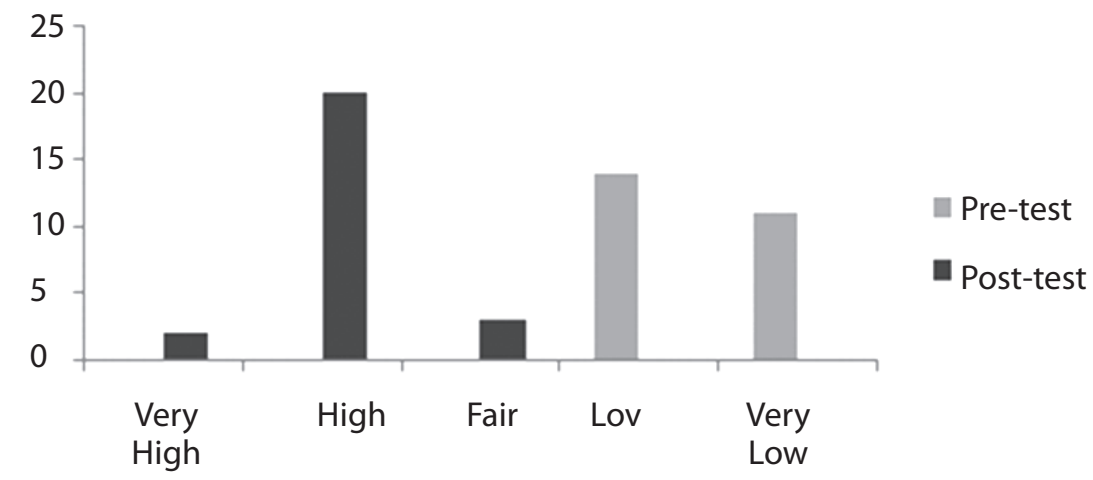

Figure 2. Statistical literacy learning achievement in the pre-test and post-test in try-out II

\section{$\mathrm{N}$-Gain calculation of statistical literacy learning achievement in the pre-test and post-test in try-out II}

$\mathrm{N}$-Gain analysis of the statistical literacy learning achievement in the pre-test and post-test is presented in Table 5 .

Table 5. N-Gain analysis of the statistical literacy learning achievement in the pre-test and post-test in try-out II

\begin{tabular}{cccccl}
\hline No & Pre-test & Post-test & Difference & N-Gain & Improvement \\
\hline 1 & 10 & 25 & 15 & 0.75 & High \\
\hline 2 & 9 & 19 & 10 & 0.48 & Moderate \\
\hline 3 & 12 & 23 & 11 & 0.61 & Moderate \\
\hline 4 & 9 & 24 & 15 & 0.71 & High \\
\hline 5 & 10 & 24 & 14 & 0.70 & High \\
\hline 6 & 11 & 22 & 11 & 0.58 & Moderate \\
\hline
\end{tabular}




\begin{tabular}{|c|c|c|c|c|c|}
\hline No & Pre-test & Post-test & Difference & N-Gain & Improvement \\
\hline 7 & 10 & 24 & 14 & 0.70 & High \\
\hline 8 & 12 & 26 & 14 & 0.78 & High \\
\hline 9 & 11 & 22 & 11 & 0.58 & Moderate \\
\hline 10 & 13 & 23 & 10 & 0.59 & Moderate \\
\hline 11 & 11 & 25 & 14 & 0.74 & High \\
\hline 12 & 9 & 22 & 13 & 0.62 & Moderate \\
\hline 13 & 11 & 21 & 10 & 0.53 & Moderate \\
\hline 14 & 10 & 21 & 11 & 0.55 & Moderate \\
\hline 15 & 10 & 25 & 15 & 0.75 & High \\
\hline 16 & 9 & 23 & 14 & 0.67 & Moderate \\
\hline 17 & 11 & 26 & 15 & 0.79 & High \\
\hline 18 & 12 & 17 & 5 & 0.28 & Low \\
\hline 19 & 13 & 22 & 9 & 0.53 & Moderate \\
\hline 20 & 14 & 18 & 4 & 0.25 & Low \\
\hline 21 & 8 & 21 & 13 & 0.59 & Moderate \\
\hline 22 & 12 & 23 & 11 & 0.61 & Moderate \\
\hline 23 & 13 & 25 & 12 & 0.71 & High \\
\hline 24 & 10 & 25 & 15 & 0.75 & High \\
\hline 25 & 14 & 21 & 7 & 0.44 & Moderate \\
\hline Mean & 10.96 & 22.68 & 11.72 & 0.61 & Moderate \\
\hline
\end{tabular}

Based on Table 5 , it can be seen that 10 or $40 \%$ of the students improved their statistical literacy learning achievement in the high category, 13 or $52 \%$ of the students improved their achievement in the moderate category, and 2 or $8 \%$ of the students improved their learning achievement in the low category. The mean score of the $\mathrm{N}$-Gain was 0.61 , i.e., the improvement of the learning achievement was in the category.

\section{Normality test in try-out II}

The result of the Kolmogorov-Smirnov test showed that the probability value of the pre-test was 0.097 , i.e., greater than the level of significance of 0.05 , then the distribution was normal. On the other hand, the probability value of the post-test was 0.200 , i.e., greater than the level of significance of 0.05 , then the distribution was also normal. It means that at the level of significance of $5 \%, \mathrm{~N}-\mathrm{Gains}$ of the pre-test and post-test scores of the statistical literacy learning achievement came from normally distributed population. 


\section{Homogeneity test in try-out II}

The result of the homogeneity test with the use of Levene's test revealed that the probability value was 0.107 , i.e., greater than the level of significance of 0.05 , then the distribution of variances of the pre-test and post-test was homogeneous. It means that at the level of significance of $5 \%, \mathrm{~N}$-Gains of the pre-test and post-test scores of the statistical literacy learning achievement came from homogeneous population.

\section{Test of significance of the learning achievement test in try-out II}

The result of the test of significance through $t$ test showed that the probability value was 0.00 , i.e., than the level of significance of 0.05 , then $\mathrm{H} 0$ was rejected. It means that at the level of significance of 5\%, N-Gains of the pre-test and post-test scores of the statistical literacy learning achievement were significantly different.

\section{Discussion}

20 respondents participated in try-out I and 25 respondents participated in try-out II, who received the pre-test. The majority of the respondents had their learning achievement categorized in the low category. It is because the students' statistical literacy skill could not help them understand the concepts, applications, calculations and interpretations of simple linear regression as the statistics material, which placed their knowledge about literacy statistics in the low category. Meanwhile, in the post-test, most of the respondents' statistical literacy learning achievement were in high category. It means that the students had understood the statistical literacy in terms of its concepts, applications, calculations and interpretations of simple linear regression so that there was an improvement in the students' statistical literacy learning achievement. However, there were still some aspects that the students had not understood, namely the applications and interpretations of simple linear regression in try-out I, and the applications of simple linear regression in try-out II.

The mean score of the N-Gains in try-out I was 0.59 , which means that the improvement of the students' statistical literacy learning achievement was in the moderate category in 11 respondents (55\%), and high category in 7 respondents (35\%). Meanwhile, the mean socre of the N-Gains in try-out II was 0.61 , which means that the improvement of the students' statistical literacy learning achievement was in the moderate category in 13 respondents (52\%), and high category in 10 respondents (40\%). 
In try-out I, the mean scores of the pre-test and post-test were 10.66 and 22.15, respectively, while in try-out II the mean scores of the pre-test post-test were 10.96 and 22.68, respectively. It means that the mean scores of the pre-test and post-test in try-out I and II were significantly different and the learning achievement in the post-test was much higher than the learning achievement in the pre-test. It was strengthened by the result of the paired sample $t$ test, which showed that the probability value of 0.000 was smaller than the level of significance of 0.05 , indicating a significant difference in statistical literacy learning achievement between the pre-test and post-test. Therefore, the use of a learning module for statistical literacy in try-out I and II was effective.

Based on try-out I and II, it can be concluded that a learning module for statistical literacy was effective. In other words, a learning module for statisical literacy was effective in improving statistical literacy learning achievement.

\section{Conclusions}

Referring to the above analysis and discussion, the researcher has come to the following conclusions: (1) there is an improvement in the students' statistical literacy learning achievement, which fell into the moderate category, (2) a learning module for statistical literacy was effective in improving statistical literacy learning achievement that consisted of some aspects of statistical literacy, i.e., concepts, applications, calculations, and interpretations of simple linear regression.

\section{References}

Borg \& Gall, 2003. Educational Research: An Introduction. Pearson Education, Inc: Boston Cobb, G. 1992. Teaching Statistics, (Heeding the Call for Change: Suggestions for Curricular Action). Dalam L.A. Steen (Ed). MAA Notes. Number 22. Washington, DC: Mathematical Association of America, 3-34.

delMas, R. 2002. Statistical Literacy, Reasoning, and Learning: A Commentary. Journal of Statistics Education, 10(3)

Evelyn \& Casey.1982. Research Methods in Education. Wadsworth Pub.Co

Gal, I. 2002. Adult's Statistical Literacy: Meanings, Components, Responsibilities. International Statistical Review, 70, 1-51

Garfield, J.B. 2002. The Challenge of Developing Statistical Reasoning. Journal of Statistics Education, 10(3). [Online].

Gregory \& Robert, J. 2000. Psychological Testing: History, Principles and Applications. Boston: Allyn and Bacon 
Joices B. dan Weil, 2011. Models of Teaching (Model-Model Pembelajaran). Edisi terjemahan. Yogyakarta: Pustaka Pelajar.

Moore, D.S. 1997. New Pedagogy and New Content: The Case of Statistics. International Statistics Review, 65(2), 123-165

Richey. R. C \& Klein. J. D, Nelson.W.A. 2000. Developmental Research: Studies Of Instructional Design and Development. Southern Illinois University at Edwardsville

Schunk. D.H. 2012. Learning Theories an Educational Perspective. Terjemahan. Edisi Keenam. Yogyakarta: PustakaPelajar

Shaughnessy, J.M. (1992). Research in Probability and Statistics: Reflections and Direction. Dalam D.A. Grouw (Ed.). Handbook of Research on Mathematics Teaching and Learning. (h. 465-494). New York: Macmillan.

Slavin,E. 1994. Educational Psychology: Theory and Practice. Massachusetts: Allyn and Bacon Publishers

Snee, R.D. (1999) Discussion: Development and Use of Statistical Thinking: A New Era. The American Statistician, 67(3), 255-258.

Walpole, R.E. and Raymond H Myers. 1995. Ilmu Peluang dan Statistika untuk Insinyur dan Ilmuwan. Edisi ke-4. [Science of opportunity and Statistics for Engineers and Scientists. $4^{\text {th }}$ Edition]. Bandung: Penerbit ITB. 